\title{
Nakba på nytt
}

I Israel har fordrivelsen av palestinerne i I948 og -49 lenge vært tabubelagt. Men i to nyere israelske romaner har nakbaen plutselig gjort sin entré. Begge romanene har blitt store salgsuksesser. Hvordan skildres nakbaen i disse bøkene, og hva kan de fortelle oss om tendenser i dagens israelske samfunn?

Av Olav Elgvin, journalist og masterstudent ved Peace and Conflict Studies ved Universitetet i Oslo.

Da jeg besøkte Israel for to år siden, kom jeg inn i en opphetet diskusjon om nakbaen, fordrivelsen av palestinerne i i948. Jeg pratet med David, en 85 år gammel pensjonert medisinprofessor som har blitt en god venn av meg. Han er på mange måter et ekstraordinært menneske: Gjennom hele sin undervisningskarriere har han prøvd å ta ekstra godt vare på de arabiske studentene, siden han vet at de føler seg som outsidere på det jødisk-dominerte universitetet. Da han ble 83 begynte han til og med å lære seg arabisk, slik at han i enda større grad skulle kunne forstå den andre siden. Men da han hørte at jeg leste en bok av historikeren Ilan Pappé eksploderte han: "Ilan Pappé? Den forræderen! Hvis jeg hadde ham her skulle jeg satt en kule rett $i$ panna hans!" Vanligvis fremtrer David som en empatisk, distingvert og sjarmerende mann. Men nå var han forvandlet: Hele kroppen var i spenn og øynene lyste. Jeg hadde aldri tidligere sett ham slik.

Da han roet seg prøvde han å forklare hva han mente. "Det som skjedde var jo at araberne ble bedt om å flykte av lederne i landene rundt. Selvfølgelig ble det en tragedie for dem. Men når Ilan Pappé skriver det han gjør, så er det ut fra et forrædersk ønske om å skade sitt eget land."
I samtalen med David kom jeg uforvarende inn på et av de største tabuene i det israelske samfunnet. Det som skjedde med palestinerne under opprettelsen av staten i I948 har vært omgitt av myter, skjønnmaling og direkte løgn.

Mange israelere vil i likhet med David fremdeles hevde at flyktningkatastrofen var «arabernes egen skyld». Andre vil kanskje strekke seg så langt som til å innrømme at det skyldtes de gjensidige krigshandlingene. Likevel vil de gjerne fremheve at krigen begynte fordi araberstatene ikke kunne godta FNs delingsplan og den jødiske staten, noe som impliserer at araberne likevel har skylden. Bare en liten minoritet vil utvetydig slå fast at de jødiske styrkene spilte en aktiv rolle i utdrivelsen, for eksempel gruppen av akademikere som har blitt kjent som nyhistorikere eller postsionister. Fra statlig hold har minnet om det arabiske Palestina fra før I948 blitt forsøkt visket $u$. Der det tidligere var palestinske landsbyer er det blant annet blitt plantet parker eller skoger som har blitt populære reisemål for israelske familier på utflukt. ${ }^{2}$

Den franske jødiske journalisten Sylvain Cypel forklarer denne benektelsen av fortiden ut fra et allmenmenneskelig behov for å rettferdiggjøre seg selv. Israelere ønsk- 
er å føle at de er de gode, mens de andre er de onde:

What is at stake in the Israelis' refusal to take responsibility for the creation of the Palestinian refugee problem is first of all their selfimage as perpetual victims of aggression. Then there is what follows from this self-image: if Israel is the victim, is only a victim, its moral superiority over its aggressor goes without saying. Thus the challenging of this moral superiority is intolerable. ${ }^{3}$

Cypel trekker fram at denne mekanismen ikke er noe som er unikt for Israel. Woody Allen spøkte for eksempel med at «the Austrians are a nation convinced that Hitler was German and Beethoven Austrian.» ${ }^{4}$ Men Israel er i motsetning til Østerrike et land som fremdeles befinner seg i daglig konflikt. De politiske konsekvensene av denne fortidsfornektelsen blir derfor langt større.

\section{Åpninger mot fortiden}

Denne artikkelen skal ikke omhandle hva som faktisk skjedde i I948, eller hvordan benektelsen av fortiden utspiller seg i dagens Israel. Derimot skal jeg ta opp hvordan palestinernes nakba plutselig har dukket opp på et uventet sted: På de skjønnlitterære bestselger-listene i Israel. I 2004 ga den unge forfatteren Eshkol Nevo ut romanen «Arba'a batim ve-ga'agoa»" - noe som kan oversettes med «Fire hus og en lengsel» (den engelske oversettelsen har fått tittelen «Homesick»). I 2008 ga den jevngamle Alon Hilu ut «Achozat Dajani», ${ }^{6}$ altså «Dajanis hus». Begge bøkene tar på en direkte måte opp palestinernes opplevelser i I948, uten å skjønnmale historien. Det paradoksale er at begge bøkene har

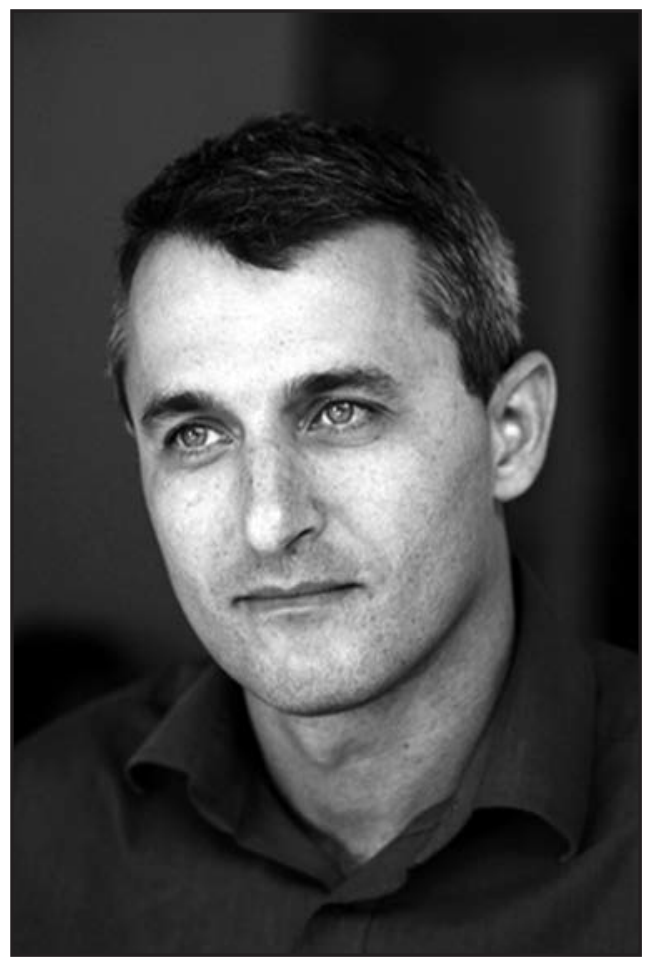

Israelske Eshkol Nevo skriver om palestinere og israelere.

blitt store salgsuksesser. Hilus bok har solgt mellom 20 o00 og 30000 siden den kom ut i februar, mens Nevo på sin side har solgt over Io० oo० eksemplarer. Dette er mye $i$ et land der mellom fire og fem millioner har hebraisk som morsmål. Hver eneste gang jeg har gått inn i en israelsk bokhandel det siste året har enten én eller begge bøkene stått på “ıo på topp"-listene eller ligget på bord merket "anbefalt litteratur”. Begge romanene har dessuten fått mye oppmerksomhet og omtale. «Dajanis hus» ble til og med anbefalt av Israels president Shimon Peres. Det er altså ikke snakk om obskure subkulturfenomener: Begge romanene har ettertrykkelig plassert seg midt i den israelske kulturen.

Disse bøkene er selvsagt ikke de første israelske romanene som omhandler møter mellom palestinere og israelere. Men 
tendensen i hebraisk litteratur har likevel vært at det er jødenes egne opplevelser som har blitt skildret. Et eksempel er Amos Oz' verdenssuksess «En fortelling om kjærlighet og mørke».7 Denne selvbiografiske, episke fortellingen omhandler livet til familien til Klausner (forfatterens familie), fra de kommer til Palestina under det britiske mandatet fram til Amos blir voksen. Perspektivet ligger hele tiden hos den jødiske familien. Slik sett er det ikke unaturlig at vi ikke møter mange palestinere. Likevel er det slående i hvilken grad palestinerne er fraværende. I beste fall er de der som en skygge, et fravær - vi kan bare ane dem forsiktig. Og fordrivelsen av palestinerne? Den nevnes bare ett sted i boka. Amos Oz er en politisk engasjert forfatter, som i sin tid var med på å starte opp den israelske fredsbevegelsen Peace Now. Likevel er denne selvbiografiske romanen - med et par unntak - renset for møter med den andre.

\section{To fortellinger, samme virkelighet?}

I det følgende vil jeg se nærmere på hvordan romanene til Hilu og Nebo skildrer nakbaen. Hilus roman foregår i årene I895-I896, men ser fram mot katastrofen som skal falle over palestinerne. Jeg begynner derfor med den.

«Dajanis hus» er en svært ambisiøs roman. Den skildrer to verdener parallelt: Den tidlige sionistiske bevegelsen, skildret gjennom den autentiske historiske personen Haim Margaliot Kalvarisky, og samtidig det palestinske samfunnet i Palestina/Jaffa anno I895, skildret gjennom den I2-årige gutten Salah Dajani. Begge de to hovedpersonene skriver dagbok, og det er slik vi blir kjent med dem. Vi får dermed aldri møte noen "objektiv" fortellerstemme, men må lappe fortellingen sammen av det gutten og den voksne mannen skriver. Etter hvert får leseren likevel et bilde av det som faktisk skjer. Vi forstår at verken Kalvarisky eller Salah er fortellere som sier hele sannheten.

Handlingen i boka er en slags Midtøsten-versjon av Shakespeares «Hamlet». I starten av fortellingen møter vi Kalvarisky

\section{ran \\ Bøkene er ikke rop om politisk

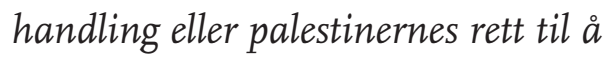 vende tilbake.}

og kona, som er på vei til Palestina fra Europa. Kalvarisky er en overbevist sionist. Han har studert landbruk, og ønsker å bruke sine evner til å skaffe jord for jødene i det lovede landet. Når de kommer til Jaffa, blir Kalvarisky desillusjonert. Samlivet med kona er ikke som han håpet. Og det går treigt med ervervelsen av jord. Men så oppdager han storgodset Dajani, der kona i huset er ung og fristende. Den seksuelt frustrerte Kalvarisky får vann i munnen. Han setter seg to mål: Erobre godset, og erobre fru Dajani.

Deretter blir vi kjent med familien Dajani. Faren i huset er bortreist store deler av året. Kona Afifa, tjenerinnen Amina og sønnen Salah er alene i huset. Salah er en svakelig og syk gutt, som likevel er rikt utrustet. Han lever livet innendørs - leser, skriver og tenker. I tillegg har han en spesiell evne: Han ser syner. Han ser fremtiden. Og det han ser er katastrofer: Araberne vil jages ut, splittes, jødene vil komme og ta over. Han skildrer det i detalj i dagboken sin: Det og det huset vil bli borte. Torget vil forsvinne. I stedet vil det bli bygget store 
tårn. Kolosser av betong. Elva i Jaffa vil legges i rør. Og araberne vil måtte flykte til andre land.

Fortellingen tar så en dramatisk vending. Herren i huset, Dajani, dør av uforklarlige årsaker. Afifa blir enke, og blir alene i det store huset. Og Salah? Han ser Kalvarisky på gaten og får for seg at den han ser er en engel! En fremmed engel, som faktisk skal bli hans redning. Han insisterer på at Kalvarisky skal inviteres inn på godset, slik at han kan bli kjent med ham. Kalvarisky vinner raskt Salahs hjerte. Etter en stund klarer han også å erobre Afifa.

Omslaget kommer da Salah oppdager at Kalvarisky har innledet et forhold til hans mor. Han oppdager også at Kalvarisky går med planer om å overta godset. Hamletmotivet forsterkes: Salah møter sin fars gjenferd. Gjenferdet forteller ham at Kalvarisky er en morder. Han drepte mannen i huset, for slik å kunne overta både frue og gård. Salah bestemmer seg for å ta opp kampen. Kalvarisky er ikke en engel, men en fiende - en fiende som må utslettes. Fortellingen beveger seg deretter mot slutten med ubønnhørlig logikk.

\section{Sionismens myter}

Selvfølgelig er dette skjønnlitteratur, og dermed ikke noe forsøk på å gi et realistisk bilde av virkeligheten. Samtidig tror jeg at forfatteren har forsøkt å si noe sant om fortiden. Før skrivingen av boka drev Hilu research $i$ to år. Kalvarisky var en viktig person i den tidlige sionistiske bevegelsen. Han var en av dens første arabister, de som jobbet opp mot det arabiske samfunnet i Palestina. I etterordet til boka skriver Hilu at Kalvarisky viet sitt liv til to prosjekter som til dels stod i motsetning til hverandre.
Han kom til Palestina for å skaffe jord til jødene. For å oppnå det kjøpte han opp land og brukte makt for å kaste ut de lokale palestinske arbeiderne. Samtidig ble han etter hvert involvert i Brit Shalom, bevegelsen av jødiske intellektuelle som ønsket å opprette en binasjonal stat. Og Kalvarisky var hele sitt liv opptatt av å bevare så gode relasjoner til araberne som mulig. I2-åringen Salah er derimot en fiktiv skikkelse. Men Dajaniene var en av de største og mest innflytelsesrike familiene i Jaffa, og i skildringen av miljøet og stedene i Jaffa har Hilu basert seg på kilder fra samtiden.

Palestinernes nakba skildres i boka på to plan. På den ene siden gjennom den faktiske handlingen - sionisten Kalvarisky kommer, ser og vinner. Først med godord og vennlighet, deretter med makt. Resultatet er tragisk. Salah dør, hans mor blir sinnsforvirret, og arbeiderne på godset som har bodd der i generasjoner blir jaget ut. I stedet kommer det jødiske bosettere, som industrialiserer godset og bygger ut markene. Men nakbaen skildres også gjennom Salahs framtidsvisjoner. Gjennom boka blir de stadig mer detaljerte, og likere og likere det dagens historikere har avdekket.

Men like mye som en fortelling om palestinernes nakba, er romanen et oppgjør med enkelte av sionismens myter. Noe av det mest slående er forskjellen på selvforståelsen til sionisten Kalvarisky, og det han faktisk gjør. Kalvarisky opplever seg selv som den moralske og siviliserte: Han har jo bare kommet for å hjelpe gutten Salah! Og faktisk: Utover i boka virker det som om Kalvarisky utvikler en genuin omsorg for den kompliserte og svakelige I2-åringen. Men Kalvarisky er ikke i stand til å forstå at grunnen til at Salah vender seg i mot ham er at Salah motsetter seg det han rent fakt- 
isk driver med: At han forsøker å overta godset Dajani. I stedet psykologiserer han Salahs motstand og mener at det bare dreier seg om et "svakelig sinn" eller "primitiv kultur”. Og når Salah virkelig blir vrang, forsøker Kalvarisky å få ham sendt til en anstalt for evneveike ungdommer.

På samme måte er det med enken Afifa. Kalvarisky utvikler en genuin omsorg for henne, og det er dessuten tydelig at han synes hun er veldig tiltrekkende. Han ønsker henne isolert sett ikke noe vondt, men når det kommer til stykket presser han henne for å få henne til å overdra eiendomsretten til ham. Hvis hun ikke gjør det, vil han offentliggiøre deres forhold, og dermed stemple henne som en løssluppen kvinne, i alles øyne. Men heller ikke dette som vi bare får høre av Salah - ser ut til å trenge inn i hans selvforståelse. Når han skriver om Afifa, er det enten med begjær eller med omsorg. Bare ett sted i boka kommer hans doble hensikter fram: Han forteller til en jemenittisk jøde hvordan han klarte å "fange kvinnen i nettet han la ut". ${ }^{8}$

Jeg leser også dette som en kritikk av dagens Israel. Israelernes selvbilde er fremdeles at de er de gode: Israeli Defence Forces (IDF) er den mest moralske hæren i verden. Palestinerne ville hatt en stat for lenge siden hvis de bare hadde kunnet oppføre seg. Årsaken til palestinernes motstand er deres primitive kultur og fanatiske legning. Og slik fortsetter det. Israels faktiske overgrep, derimot, finner i liten grad veien til bevisstheten. Det skyves unna - til et par spaltister i avisa Haaretz, til venstreside-foreningene i Tel Aviv, til de opprørske tenåringene med palestinaskjerf.

Samtidig bærer Israel fremdeles med seg spenningene vi finner i karakteren Viktor Kalvarisky. På den ene siden er det en stat som diskriminerer på bakgrunn av etnisitet, en okkupasjonstmakt, en av de få statene i verden som fremdeles har klare koloniale trekk. På den annen side er Israel likevel et demokrati (innenfor den grønne linjen). Palestinske borgere av staten Israel har mer ytringsfrihet enn de ville hatt $\mathrm{i}$ de arabiske landene rundt. Og den kritiske, humanistiske tradisjonen i jødedommen har aldri blitt borte fra samfunnslivet. Den har i perioder vært svak, og i de fleste politiske spørsmål har den måttet vike for realpolitikken. Men den har vært der. Slik også Kalvarisky er en blanding av humanisme og kynisk maktbruk.

\section{Et hjem for oss, et hjem for deg}

Eshkol Nevos «Fire hus og en lengsel» er en helt annen type roman. Den er ikke like historisk ambisiøs som «Dajanis hus». Men Nevo skriver lettere og mer sjarmerende. På tross av dystre elementer blir det likevel en feelgood-roman: Etter å ha lest den sitter man igjen med en følelse av at ting ordner seg, det blir bedre, det er faktisk ikke så ille!

Heller ikke denne romanen henter handlingen direkte fra I948. Handlingen foregår i I990-årenes Israel. Den skildrer tre israelske nabofamilier i nabolaget Kastel utenfor Jerusalem. Menneskene vi blir kjent med utgjør et tverrsnitt av det israelske samfunnet: Det unge studentekteparet Amir og Noa som er ashkenazim, altså israelere av europeisk herkomst. De er akademiske, kompliserte og lettere nevrotiske - nokså nær det stereotype bildet av ashkenazim i Israel. På andre siden av veggen bor Sima og Moshe, et par som er deres totale motsetning. De er mizrahim, altså jøder av orientalsk/arabisk herkomst. Også de oppfyller det stereotype bildet av 
mizrahim: Lavt utdannede, ikke-akademiske og med hang til mystisisme og religion. Paret ble tidlig gift, har flere barn og fremstår som varme, vennlige og relativt ukompliserte. Rett over gata bor en annen familie, som har opplevd en typisk israelsk tragedie: Eldstesønnen er blitt drept i militærtjeneste. Mens moren sørger, reagerer faren gjennom å bli enda mer nasjonalistisk. Han blir enda mer besatt av sikkerhet og går enda mer opp i jobben.

Handlingen veksler mellom disse tre parene, og gir et bilde av vanlige konfliktlinjer i det israelske samfunnet. Det personlige møter det politiske: Et av parene opplever en religiøs konflikt, der den ene vil oppdra barnet tradisjonelt jødisk, mens den andre ønsker en sekulær oppdragelse. Studentekteparet opplever klassiske blivoksen-kvaler: Skal de leve sammen? Hva skal de leve av? Som mange andre unge lurer de på om de i det hele tatt ønsker å bli i Israel, eller om de skal søke en bedre framtid et annet sted. Og familien som har mistet en sønn, gjennomlever det nasjonale traumet: Å miste noen man elsker, i det som oppleves som en kamp for egen eksistens.

Så langt kunne «Fire hus og en lengsel» vært en hvilken som helst hebraisk roman om interne israelske forviklinger. Det som gjør den fascinerende er at palestinernes historie veves inn i dette. Palestinernes erfaring og palestinernes sorg blir presentert side om side med israelernes virkelighet. Ikke som noe fremmed eller mindreverdig, men som en del av den komplekse israelske virkeligheten. I tillegg til disse tre jødiske historiene blir vi nemlig kjent med en fjerde historie. Den palestinske bygningsarbeideren Saddiq kommer en dag til Kastel for å bygge et hus. Når han ser huset der Amir, Noa, Sima og Moshe bor, så virker det kjent: Har han ikke vært her før? Da husker han det: Dette var hans barndomshjem. Som liten ble han jaget ut herfra.

Etter hvert former det seg et oppdrag i Saddiqs hode. Han vil gå inn i huset, og han vil konfrontere dem som bor der. Han ønsker å finne familiens arvestykke, et gullkjede som fremdeles skal være gjemt i et hulrom i veggen. Saddiq utfører det han bestemmer seg for. Men det går ikke som han hadde tenkt. Han blir ikke noen helt. Han endrer ikke historien. I stedet blir han sendt i fengsel for ordensforstyrrelse.

\section{Nakbaen i dag}

Tematisk tar Nevos bok opp tråden der «Dajanis hus» slapp, selv om den ble skrevet noen år tidligere. «Dajanis hus» skildret det som skjedde. Nevo skildrer virkeligheten i dag, hvordan nakbaen fremdeles er til stede, dels i palestinernes bevissthet, og dels som en fortrengt del av den israelske virkeligheten. Kan vi lese noe politisk budskap ut av boka? Ikke direkte. Alle de interne jødiske forviklingene finner sin løsning. Amir og Noa finner ut at de vil satse på et liv sammen. Sima og Moshe kommer fram til et modus vivendi når det gjelder religion og oppdragelse. Og familien som mistet sønnen, klarer å bryte isen som satte seg hos dem da sønnen døde. Men konflikten mellom Saddiq, den palestinske flyktningen, og jødene som bor i hans gamle hus, finner ikke noen løsning. Saddiq blir sendt i fengsel, der han tenker bitre tanker om israelerne - samtidig som han mest av alt lengter hjem til sin egen familie. Israelerne fortsetter sine liv. De har blitt oppmerksomme på at noen bodde der før dem, en gang i tiden. Men det virker ikke som om det ryster dem noe særlig. De 
registrerer situasjonen, men resultatet er bare at de tenker at de framover skal prøve å vise litt mer forståelse overfor palestinerne.

Kanskje er det nettopp dette - økt forståelse - Hilu og Nevo prøver å få fram? Bøkene er ikke et rop om noen spesifikk politisk handling eller palestinernes rett til å vende tilbake. Heller kan bøkene leses som et ønske om erkjennelse og selverkjennelse. I et felles intervju i Haaretz fra april $2008^{9}$ erklærer de seg begge som sionister. De er definitivt tilhengere av en jødisk stat. Men de mener at israelere må erkjenne hva som har skjedd for å kunne finne løsninger. Nevo, som forøvrig er barnebarn av tidligere statsminister Levi Eshkol, sier det slik til Haaretz:

There is emotional justice in the Palestinian narrative, and it is important that it be studied and heard. The challenge is how to deal with it without ceasing to be a Zionist, without losing the meaning of our existence here.

Det er altså langt fra Nevo og Hilu til en antisionist som historikeren Ilan Pappé, til tross for at fortellingene deres om nakbaen ligner på hverandre. Nevo og Hilu hevder i Haaretz-intervjuet at deres generasjon kan nærme seg nakbaen nettopp fordi det ikke lenger er politisk truende. Den israelske staten er relativt trygg, tross alt, og nyter bred legitimitet internasjonalt. Med en slik grunnleggende sikkerhet går det an å nærme seg ubehagelige episoder i egen historie.

\section{Litterær kolonialisme?}

Fra et normativt ståsted kan man stille spørsmål om hvilken betydning disse bøkene har, og om de kan bane vei for en bedre og mer rettferdig framtid? Et kritisk syn kan vi finne hos eksil-israeleren og sosiologen Ronit Lentin ${ }^{\text {10}}$. Lentin mener at israelske representasjoner av nakbaen faktisk kan utgjøre et nytt overgrep mot palestinerne. Konkret retter hun kritikken sin mot virksomheten til den israelske organisasjonen Zochrot som jobber for å opplyse israelerne om nakbaen og landets arabiske fortid. Men kritikken vil også kunne utvides til å gjelde forfattere som Hilu og Nevo.

Ifølge Lentin kan israelske og/eller jødiske representasjoner av nakbaen frata palestinerne deres stemme: Palestinerne blir slik kolonialisert en gang til. Forskjellen er at det denne gangen ikke er landet deres som blir tatt fra dem, men deres historie. Den blir «overtatt» av israelerne, som forteller den på deres vegne. I tillegg kan de israelske representasjonene av nakbaen ufarliggjøre palestinernes historie. Nakbafortellingen blir fortalt uten noe tilhørende krav om rett til hjemvendelse: Den blir fortalt rett og slett som historie, som fortelling, men ikke som noe som har moralske eller juridiske implikasjoner. Sitatet over fra Nevo bekrefter kanskje Lentins argument: Historien om nakbaen må fortelles, men deres krav er noe vi ikke kan ta inn over oss. Nevos formulering "emotional justice" er verdt å merke seg i denne sammenhengen.

Er det noe i Lentins kritikk? Kanskje. En av grunnene til at romanene til Hilu og Nevo har nådd såpass bredt ut kan være at de forteller om nakbaen uten å gjøre det politisk truende. Leserne kan dermed trekke sine egne konklusjoner, og kan velge å se bort fra palestinernes juridiske og moralske rettigheter. Samtidig opplever jeg Lentins kritikk som i overkant akademisk og virkelighetsfjern. Dersom man må velge 
mellom det som har vort den israelske virkeligheten - nemlig en total benektelse av det som skjedde i i948 - og en "tannløs" erkjennelse av palestinernes historie, så er ikke jeg i tvil om at det siste bør velges. En israelsk erkjennelse av fortiden kan nemlig få politiske konsekvenser. Én dimensjon er den symbolske: Dersom israelerne anerkjente palestinernes tap, ville det innebære en symbolsk oppreisning for palestinerne. I ødelagte relasjoner mellom mennesker kan det få stor betydning dersom en av partene rett og slett sier: "Unnskyld. Jeg gjorde en feil. Jeg vil forsøke å gjøre det godt igjen, så langt jeg klarer.” Noe tilsvarende kan gjelde i forholdet mellom israelerne og palestinerne, selv om det selvfølgelig er forskjell på forhold mellom mennesker og forhold mellom folkegrupper.

Også mer umiddelbart er det viktig med en israelsk erkjennelse av fortiden. Min erfaring er at mange israelere rett og slett ikke forstår hvorfor palestinerne har gjort opprør. Det skal dreie seg om eldgammelt jødehat, om islamsk antisemittisme, om en primitiv kultur som ikke kan takle den jødiske moderniteten. Eksempler på denne tenkemåten finner vi hos flere av intervjuobjektene i intervjuboka «Occupied Minds». ${ }^{\text {II }}$ Selvfølgelig kan det være noe i noe av dette. Men med dette utgangspunktet blir det umulig å finne konstruktive løsninger. Hvordan forhandler du med en som rett og slett hater deg fordi du er deg? Det er opplagt ganske vanskelig.

Dersom forfattere som Hilu og Nevo klarer å endre det mentale bildet israelere har av konflikten, kan det kanskje bidra til å endre selve konflikten. Dersom israelere flest forstod at det er relativt enkle årsaker til palestinernes motstand - nemlig den etniske rensingen i I948, og senere okkupasjonen fra I967 - så ville de bli bedre rustet til å tenke kreativt om framtiden. Det betyr ikke at konflikten vil være enkel å løse, sett fra israelernes perspektiv. Men det kan bety at konflikten vil være mulig å løse: Den er ikke hugget i stein, den er ikke et resultat av en evig, årtusenlang sivilisasjonskonflikt. Nettopp derfor er det svært positivt at det begynner å komme israelske representasjoner av nakbaen, både i israelsk skjønnlitteratur og sakprosa - hvor mangelfulle de enn måtte være.

\section{$\cdot f \cdot$}

I Takk til Torleif Elgvin for innspill underveis i skriveprosessen, og til Trude Strand og Naima Mouhleb for verdifull tilbakemelding på et tidligere utkast.

2 Se for eksempel Pappé, Ilan: «The Ethnic Cleansing of Palestine», kapittel Io. Oxford: Oneworld, 2006.

3 Cypel, Julian: «Walled. Israeli Society at an Impasse», side 44. New York: Other Press, 2006.

4 Sitert i Cypel, Julian: «Walled. Israeli Society at an Impasse», side 73. New York: Other Press, 2006

5 Nevo, Eshkol: «Arba'a batim ve-ga'goa» (Fire hus og en lengsel). Kinneret: Zmora Bitan, 2004.

6 Hilu, Alon: «Achozat Dajani» (Dajanis hus). Tel Aviv: Yediot Achronot Books / Chemed Books, 2008.

7 Oz, Amos: «En fortelling om kjærlighet og mørke». Oslo: Pax, 2004.

8 Hilu, Alon: «Achozat Dajani» (Dajanis hus), side 3ı6. Tel Aviv: Yediot Achronot Books / Chemed Books, 2008

9 Haaretz Online: haaretz.com/hasen/spages/97I506.html

Io Lentin, Ronit: “The Contested Memory of Dispossession: Commemorizing the Palestinian Nakba in Israel", i Lentin, Ronit (red.): «Thinking Palestine». London: Zed Books, 2008.

II Neslen, Arthur: «Occupied Minds. A Journey through the Israeli Psyche». London: Pluto Press, 2006. 